\title{
A New Dataset of Delegate Positions on All Substantive Roll Calls at the U.S. Constitutional Convention
}

\author{
KEITH DOUGHERTY \\ Department of Political Science \\ University of Georgia \\ JAC HECKELMAN \\ Department of Economics \\ Wake Forest University \\ PAUL CARLSEN \\ Department of Political Science \\ University of Georgia \\ DAVID GELMAN \\ Department of Political Science \\ University of Rochester
}

\begin{abstract}
Delegate level analysis of the U.S. Constitutional Convention has been limited because the Convention did not record delegate votes. In this article, we introduce the Constitutional Convention Research Group Dataset, which contains 5,121 inferred delegate votes on 620 substantive roll calls at the Convention. The Constitutional Convention Research Group Dataset represents a significant improvement over previous datasets such as those compiled by McDonald (1958) and Dougherty and Heckelman (2009), and datasets based on votes recorded for state blocs (Jillson 1981, 1988).
\end{abstract}

Keywords: dataset, Constitutional Convention, roll call voting, American history

$\mathrm{T}$ he study of the U.S. Constitutional Convention has long been a central focus of both historians and political scientists. However, individual-level analysis has been elusive because there is no official record of how each delegate voted at Independence Hall. Madison took notes on the happenings of the Convention, but he rarely recorded the

Funding for this research was supported by the National Science Foundation, SES-0752098.

Address correspondence to Keith Dougherty, Department of Political Science, University of Georgia, 104 Baldwin Hall, Athens, GA 30602, USA. E-mail: dougherk@uga.edu votes of individual delegates. Instead, he recorded the votes of the state blocs as done in the Convention journal. Previous researchers have attempted to infer votes for the 55 delegates, but these efforts have produced very small datasets. In this article, we introduce a new, comprehensive data set of inferred delegate positions for each substantive roll call ${ }^{1}$ at the Convention, called the Constitutional Convention Research Group Dataset (CCRG Dataset; Keith Dougherty and Jac Heckelman 2011). In total, the CCRG Dataset contains 5,121 inferred yea or nay positions for delegates on substantive issues, 4,417 more positions than the most comprehensive dataset currently available (a $627 \%$ increase).

The dataset was gathered over the course of two and a half years through the joint effort of the University of Georgia and Wake Forest University under the supervision of Keith Dougherty and Jac Heckelman. The project was made possible by a grant from the National Science Foundation (SES-0752098). The database contains a roll call matrix, which includes the positions inferred for each delegate, information about each delegate in attendance, and an issue category for the roll call. It also includes a codebook describing each roll call in some detail. Personal information collected about the delegates (including religion, education, 
prior political experience, etc.) is available from Dougherty and Heckelman upon request.

\section{Previous Constitutional Delegate Level Datasets}

By the rules of the Convention, the position of each state (yea, nay, or divided) was determined by a simple majority of the state's delegates. In order to promote candid discussion, the Convention journal did not record delegate votes. It recorded only the votes of the state blocs.

Forrest McDonald (1958) provided the first systematic attempt to infer delegate positions using information from the state blocs. McDonald focused exclusively on 16 roll calls that covered a variety of issues at the Convention, and inferred 549 delegate positions on those roll calls. As Heckelman and Dougherty (2007) suggest, McDonald may have deciphered individual positions by assuming that delegates voted consistent with the vote recorded for their state bloc unless he had information suggesting otherwise. Such information included motions and speeches made by delegates in debate, as well as statements from other manuscripts.

Until the last few years, individual-level analysis of the Philadelphia Convention utilized the votes inferred by McDonald or slight variations thereof. For example, Robert McGuire and Robert Ohsfeldt $(1984,1986)$ filled in codes for the Pennsylvania delegates (which McDonald did not attempt to infer) by assuming all the Pennsylvania delegates voted unanimously. They also added codes for the three Delaware delegates on roll call 559 that McDonald intentionally left uncoded, and filled in positions for delegates not in attendance on any particular roll call using various assumptions, primarily based on the delegate's support for the final version of the Constitution (McGuire and Ohsfeldt 1984, 1986).

McDonald's and McGuire and Ohsfeldt's work greatly increased our understanding of the Constitutional Convention and the subsequent Constitution, but the McDonald data, and its variants, have their limitations. For example, McDonald did not infer a position for any delegate from Pennsylvania because he was uncertain whether his methodology applied to a delegation with eight members that had only two delegates speaking regularly. He believed such factors would make it difficult to determine the voting behavior of the Pennsylvania delegates. As noted above, McGuire and Ohsfeldt (1986) would later adjust for McDonald's omission by assuming that the Pennsylvania delegates voted unanimously on all roll calls. But because state votes were determined by a majority of the state's delegates, not by unanimity rule, there are reasons to question this assumption.

The CCRG Dataset suggests that the Pennsylvania delegation was not unanimous on roughly $17 \%$ of the examined roll calls, ${ }^{2}$ despite the fact that all of the Pennsylvania delegates came from the same city and allegedly had similar backgrounds (McGuire 2003). Such discrepancies raise concerns over the veracity of assuming unanimity among any delegation.
Perhaps the biggest concern with McDonald's data is that it covers only 16 of the 797 roll calls at the Convention. ${ }^{3}$ In an attempt to increase the sample size, Dougherty and Heckelman (2009; hereafter DH) recoded McDonald's 16 roll calls and expanded McDonald's data set by an additional 12 roll calls. However, DH used all available information about a delegate to determine his position on the 28 roll calls analyzed. This includes information about delegate positions on issues within their state legislatures, which might date back a half dozen years before the Convention, and statements made on earlier or later roll calls at the Convention. The obvious limitation of this approach is that it does not allow delegates to change positions over time. Furthermore, even though the DH sample spans a larger number of roll calls, it is still limited to 28 motions.

To determine whether either McDonald's 16 or DH's 28 accurately represent the substantive roll calls at the convention, we created 26 categories to classify each of the substantive roll calls, and counted the proportion of McDonald's roll calls and DH's roll calls in each category. Table 1 lists the breakdown.

It is readily apparent that neither the 16 roll calls identified by McDonald nor the 28 roll calls inferred by DH are representative of the roll calls at the Convention. Several issues, like legislative selection and powers of the state governments, are significantly overrepresented in these two datasets, while issues like legislative apportionment and executive powers (two important issues at the Convention) are not represented at all.

\section{Inferring Delegate Positions}

To address these shortcomings, the CCRG Dataset attempts to infer delegate votes on all substantive roll calls at the Constitutional Convention based on Max Farrand's (1966) The Records of the Federal Convention of 1787 and James Hutson's (1987) supplement. Delegate votes in the CCRG Dataset were recovered in a three-step process.

The first step was to determine which delegates were in attendance, ${ }^{4}$ and to assign a delegate the vote recorded for his state if his delegation had no more than two members attending. ${ }^{5}$ By the formal rules of the Convention, each state's vote was determined by a majority of its delegation. Hence, if two delegates attended and the state was recorded as yea (nay), then both of the delegates must have voted yea (nay). For example, on vote 387 to prohibit the states from issuing paper currency, Georgia is recorded as a yea. Thus, Abraham Baldwin and William Few were both coded yea because they were the only delegates from Georgia in attendance. Cases where the state was divided or the vote recorded for the state did not match in both Madison's notes and the journal were not coded in this step.

Additional delegate votes were inferred in the second step using statements made by delegates in debate, as recorded in the notes of James Madison, Robert Yates, Rufus King, 
TABLE 1. Roll Call Categories

\begin{tabular}{|c|c|c|c|}
\hline Category & $\begin{array}{l}\text { \# All roll } \\
\text { calls }(\%)\end{array}$ & $\begin{array}{c}\text { \# McDonald } \\
16(\%)\end{array}$ & $\begin{array}{c}\# \text { DH } \\
28(\%)\end{array}$ \\
\hline Judicial composition and process & $18(2.26)$ & $0(0.00)$ & $0(0.00)$ \\
\hline Judicial powers & $22(2.76)$ & $1(6.25)$ & $1(3.57)$ \\
\hline Judicial selection & $3(0.38)$ & $0(0.00)$ & $0(0.00)$ \\
\hline Judicial qualifications & $1(0.13)$ & $0(0.00)$ & $0(0.00)$ \\
\hline Legislative composition and process & $101(12.67)$ & $2(12.50)$ & $2(7.14)$ \\
\hline Legislative powers & $119(14.93)$ & $2(12.50)$ & $6(21.43)$ \\
\hline Legislative selection & $20(2.51)$ & $1(6.25)$ & $6(21.43)$ \\
\hline Legislative qualifications & $27(3.39)$ & $0(0.00)$ & $0(0.00)$ \\
\hline Legislative apportionment & $59(7.40)$ & $0(0.00)$ & $0(0.00)$ \\
\hline Executive composition and process & $38(4.77)$ & $0(0.00)$ & $0(0.00)$ \\
\hline Executive powers & $44(5.52)$ & $0(0.00)$ & $0(0.00)$ \\
\hline Executive selection & $38(4.77)$ & $0(0.00)$ & $0(0.00)$ \\
\hline Executive qualifications & $6(0.75)$ & $1(6.25)$ & $1(3.57)$ \\
\hline Powers of state governments & $35(4.39)$ & $4(25.00)$ & $5(17.85)$ \\
\hline General powers of national government & $23(2.89)$ & $1(6.25)$ & $1(3.57)$ \\
\hline Defense policy & $8(1.00)$ & $1(6.25)$ & $1(3.57)$ \\
\hline Regulations & $3(0.38)$ & $0(0.00)$ & $0(0.00)$ \\
\hline Spending and taxation & $20(2.51)$ & $1(6.25)$ & $3(10.71)$ \\
\hline Monetary policy & $6(0.75)$ & $0(0.00)$ & $0(0.00)$ \\
\hline Other policy & $1(0.13)$ & $0(0.00)$ & $0(0.00)$ \\
\hline Rights and responsibilities of citizens & $1(0.13)$ & $0(0.00)$ & $0(0.00)$ \\
\hline Qualifications of electors & $9(1.13)$ & $0(0.00)$ & $0(0.00)$ \\
\hline Amendments and ratifications & $31(3.90)$ & $2(12.50)$ & $2(7.10)$ \\
\hline Procedural motions & $119(14.93)$ & $0(0.00)$ & $0(0.00)$ \\
\hline Other & $30(3.76)$ & $0(0.00)$ & $0(0.00)$ \\
\hline Content could not be identified & $15(1.88)$ & $0(0.00)$ & $0(0.00)$ \\
\hline Total & $797(100.00)$ & $16(100.00)$ & $28(100.00)$ \\
\hline
\end{tabular}

and other delegates (collected in Farrand 1966). The CCRG Dataset also uses statements from personal manuscripts and speeches published in Farrand's (1966) volume 3 or the supplement (Hutson 1987), but only if they could be tied to a particular roll call on a particular day. To allow for preference changes, a statement was applied to a roll call only if it came from the debate on that particular roll call. ${ }^{6}$ For example, Nathaniel Gorham, a member of the Massachusetts delegation, was inferred as voting nay on vote 387 because in response to the motion to add an absolute prohibition of state currency to Article XII (of the resolves of the Committee of Detail), Gorham said the purpose of the clause was already protected in Article XIII which required the consent of the national legislature for the states to issue currency. He further claimed "an absolute prohibition would rouse the most desperate opposition from its partizans" (Farrand 1966, 2:439). George Read, from Delaware, strongly opposed paper currency two weeks earlier, but he was not coded on vote 387 because his statement was not directly related to the debate on vote $387 .^{7}$

In the third step, attendance records were again examined, this time to determine whether additional delegate votes could be inferred from the state's vote and the fact that each state's vote was determined by a majority of its delegates. For example, Massachusetts was recorded as a yea on vote 387 . Because Caleb Strong was absent and Gorham was coded as nay, the two remaining Massachusetts delegates, Elbridge Gerry and Rufus King, must have voted yea in order for a majority of the Massachusetts delegation to have voted yea.

The CCRG made no attempt to infer delegate positions on procedural roll calls, including motions to adjourn, postpone, commit, or reconsider. However, positions were inferred on motions to postpone, if the motion was substantively important. $^{8}$

To anticipate concerns about inter-coder reliability, all roll calls were coded by two independent coders. A pair of coders, when faced with identical information, agreed roughly $80 \%$ of the time. In cases of disagreement, the two coders met to review the issue. If the coders still disagreed, the code was discussed at a weekly discussion group consisting of all the coders, a graduate supervisor, and the lead professor. A code would be included only if a consensus could be reached about the proper code. The group erred in favor of missing values. 


\section{The Data}

The process outlined above produced an average of 93 vote inferences per delegate with an average of eight inferences per roll call. Baldwin has the most codes with 451 inferences, while William C. Houston (NJ), who left the convention after one week and never spoke in the debates, has no codes. In all, the CCRG Dataset contains 5,121 yea or nay votes out of an estimated 25,928 potential votes cast on 620 substantive roll calls. Table 2 provides a complete listing of the number of inferred votes for each delegate. By comparison, DH contains 704 out of an estimated 1,179 potential votes covering 28 roll calls and McDonald contains 547 out of 678 potential votes on 16 roll calls.

The average delegate was coded yea or nay on roughly $20 \%$ of all roll calls for which a delegate attended. Four delegates-Gilman (NH), Langdon (NH), Baldwin (GA), and Few (GA)-had a position inferred on more than $70 \%$ of the roll calls for which they attended. Each came from a delegation that had two delegates in attendance for most, if not all, of the days they were at the convention. Thus, they were largely coded based on the vote recorded for their state.

Some scholars have found it simpler to use the votes recorded for the state blocs and have implicitly assumed unanimity among delegates from the same state. Yet, the CCRG Dataset suggests that delegates did not always vote the same as the majority of their delegation. Table 3 reports the number of times a delegate's inferred position was the same as that of their state, and what proportion of the delegate's positions aligned with the vote of their state bloc.

There are only nine delegates for whom their vote inference is always the same as the vote recorded for their state, and seven of those delegates have fewer than 12 inferred positions. The remaining two are the delegates from New Hampshire who could never have disagreed with each other unless the state vote was recorded as divided, which occurred only 11 times. In each of these 11 cases, their individual positions could not be inferred. Thus, in reality we know they were unified on only $97 \%$ of the roll calls, rather than the $100 \%$ reported in the table.

Conversely, 46 delegates voted on the minority side of their state on at least one roll call, and nine of those delegates voted against their state bloc on more than $30 \%$ of roll calls where positions could be inferred. This includes delegates like Gerry (MA), Hamilton (NY), and Mason (VA), who were notorious dissenters in their delegations. These findings raise questions about studies that rely strictly on state votes (e.g., Jillson 1981, 1988; Slez and Martin 2007; Pope and Treier 2011) or studies that assume all delegates in a state voted unanimously in order to infer delegate votes (McGuire and Ohsfeldt 1984, 1986).

Because the protocol used by the CCRG allowed for preference changes across the course of the convention, the CCRG Dataset naturally contains fewer positions per roll call than the DH 28. Table 4 compares the
TABLE 2. Summary of Inferred Positions in the CCRG Dataset

\begin{tabular}{|c|c|c|c|c|}
\hline Delegate & State & $\begin{array}{l}\text { Number of } \\
\text { positions } \\
\text { inferred }\end{array}$ & $\begin{array}{l}\text { Number of } \\
\text { potential } \\
\text { positions }\end{array}$ & $\begin{array}{l}\text { Proportion } \\
\text { coded }\end{array}$ \\
\hline Gilman & $\mathrm{NH}$ & 374 & 424 & 0.88 \\
\hline Langdon & $\mathrm{NH}$ & 374 & 424 & 0.88 \\
\hline Baldwin & GA & 451 & 557 & 0.78 \\
\hline Few & GA & 366 & 513 & 0.71 \\
\hline Sherman & $\mathrm{CT}$ & 333 & 588 & 0.57 \\
\hline Houstoun & GA & 94 & 197 & 0.48 \\
\hline Johnson & $\mathrm{CT}$ & 251 & 575 & 0.44 \\
\hline Yates & NY & 48 & 126 & 0.38 \\
\hline Madison & VA & 230 & 620 & 0.37 \\
\hline Morris, G. & PA & 181 & 509 & 0.36 \\
\hline Ellsworth & $\mathrm{CT}$ & 135 & 381 & 0.35 \\
\hline Martin & MD & 139 & 393 & 0.35 \\
\hline Hamilton & NY & 57 & 164 & 0.35 \\
\hline Wilson & PA & 189 & 616 & 0.31 \\
\hline Lansing & NY & 30 & 103 & 0.29 \\
\hline Gerry & MA & 158 & 548 & 0.29 \\
\hline Mason & VA & 162 & 620 & 0.26 \\
\hline King & MA & 129 & 565 & 0.23 \\
\hline Gorham & MA & 129 & 588 & 0.22 \\
\hline Randolph & VA & 124 & 619 & 0.20 \\
\hline Williamson & $\mathrm{NC}$ & 119 & 595 & 0.20 \\
\hline Mercer & MD & 23 & 188 & 0.20 \\
\hline Jenifer & MD & 117 & 605 & 0.19 \\
\hline Pinckney, C. & $\mathrm{SC}$ & 107 & 620 & 0.17 \\
\hline Rutledge & $\mathrm{SC}$ & 101 & 618 & 0.16 \\
\hline Strong & MA & 59 & 397 & 0.15 \\
\hline Butler & $\mathrm{SC}$ & 92 & 620 & 0.15 \\
\hline Pinckney, C.C. & $\mathrm{SC}$ & 81 & 620 & 0.13 \\
\hline Dickinson & $\mathrm{DE}$ & 68 & 584 & 0.12 \\
\hline Pierce & GA & 12 & 105 & 0.11 \\
\hline Carroll & MD & 52 & 502 & 0.10 \\
\hline Paterson & $\mathrm{NJ}$ & 17 & 169 & 0.10 \\
\hline McHenry & MD & 28 & 409 & 0.07 \\
\hline Read & VA & 40 & 614 & 0.06 \\
\hline Dayton & NJ & 25 & 468 & 0.05 \\
\hline Franklin & PA & 32 & 615 & 0.05 \\
\hline Wythe & VA & 1 & 20 & 0.05 \\
\hline Spaight & $\mathrm{NC}$ & 28 & 593 & 0.05 \\
\hline Davie & $\mathrm{NC}$ & 13 & 295 & 0.04 \\
\hline Washington & VA & 25 & 619 & 0.04 \\
\hline Blair & VA & 22 & 620 & 0.04 \\
\hline Bedford & $\mathrm{DE}$ & 18 & 613 & 0.03 \\
\hline McClurg & VA & 6 & 212 & 0.03 \\
\hline Broom & $\mathrm{DE}$ & 16 & 612 & 0.03 \\
\hline Brearley & NJ & 12 & 519 & 0.02 \\
\hline Blount & $\mathrm{NC}$ & 8 & 423 & 0.02 \\
\hline Fitzsimmons & PA & 10 & 615 & 0.02 \\
\hline Clymer & PA & 9 & 615 & 0.01 \\
\hline Livingston & $\mathrm{NJ}$ & 4 & 435 & 0.01 \\
\hline Martin & $\mathrm{NC}$ & 9 & 401 & 0.01 \\
\hline Morris, R. & PA & 5 & 615 & 0.01 \\
\hline Bassett & $\mathrm{DE}$ & 4 & 613 & 0.01 \\
\hline Ingersoll & PA & 2 & 615 & $<0.01$ \\
\hline Mifflin & PA & 2 & 615 & $<0.01$ \\
\hline Houston & NJ & 0 & 19 & 0.00 \\
\hline Totals & & 5,121 & 25,928 & $0.20(\mathrm{avg})$ \\
\hline
\end{tabular}

Note. Both Wythe (VA) and Houston (NJ) have few potential positions because they fell sick and went home within two weeks of the start of the Convention. 
TABLE 3. Proportion of Times a Delegate Is on the Majority Side of His State

\begin{tabular}{|c|c|c|c|}
\hline Delegate & State & $\begin{array}{c}\text { Number } \\
\text { of agreements }\end{array}$ & $\begin{array}{l}\text { Percentage } \\
\text { of agreement }\end{array}$ \\
\hline Gilman & $\mathrm{NH}$ & 374 & 100 \\
\hline Langdon & $\mathrm{NH}$ & 374 & 100 \\
\hline Gerry & MA & 89 & 56 \\
\hline Gorham & MA & 110 & 85 \\
\hline King & MA & 103 & 80 \\
\hline Strong & MA & 53 & 90 \\
\hline Ellsworth & $\mathrm{CT}$ & 126 & 93 \\
\hline Johnson & $\mathrm{CT}$ & 243 & 97 \\
\hline Sherman & CT & 314 & 94 \\
\hline Hamilton & NY & 20 & 40 \\
\hline Lansing & NY & 29 & 97 \\
\hline Yates & NY & 42 & 88 \\
\hline Brearley & NJ & 12 & 100 \\
\hline Dayton & NJ & 22 & 88 \\
\hline Houston & NJ & - & - \\
\hline Livingston & NJ & 4 & 100 \\
\hline Paterson & NJ & 15 & 88 \\
\hline Clymer & PA & 7 & 78 \\
\hline Fitzsimmons & PA & 7 & 70 \\
\hline Franklin & PA & 19 & 59 \\
\hline Ingersoll & PA & 2 & 100 \\
\hline Mifflin & PA & 2 & 100 \\
\hline Morris, G. & PA & 135 & 75 \\
\hline Morris, R. & PA & 1 & 20 \\
\hline Wilson & PA & 137 & 72 \\
\hline Bassett & DE & 3 & 75 \\
\hline Bedford & DE & 14 & 78 \\
\hline Broom & DE & 12 & 75 \\
\hline Dickinson & DE & 44 & 65 \\
\hline Read & DE & 23 & 58 \\
\hline Carroll & MD & 43 & 83 \\
\hline Jenifer & MD & 105 & 90 \\
\hline Martin & MD & 107 & 77 \\
\hline McHenry & MD & 23 & 82 \\
\hline Mercer & MD & 17 & 74 \\
\hline Blair & VA & 19 & 86 \\
\hline Madison & VA & 171 & 74 \\
\hline Mason & VA & 109 & 67 \\
\hline McClurg & VA & 6 & 100 \\
\hline Randolph & VA & 90 & 73 \\
\hline Washington & VA & 22 & 88 \\
\hline Wythe & VA & 1 & 100 \\
\hline Blount & $\mathrm{NC}$ & 8 & 100 \\
\hline Davie & $\mathrm{NC}$ & 11 & 85 \\
\hline Martin & $\mathrm{NC}$ & 6 & 67 \\
\hline Spaight & $\mathrm{NC}$ & 22 & 79 \\
\hline Williamson & $\mathrm{NC}$ & 94 & 79 \\
\hline Butler & $\mathrm{SC}$ & 77 & 84 \\
\hline Pinckney, C.C. & $\mathrm{SC}$ & 77 & 95 \\
\hline Pinckney, C. & $\mathrm{SC}$ & 85 & 79 \\
\hline Rutledge & $\mathrm{SC}$ & 93 & 92 \\
\hline Baldwin & GA & 448 & 99 \\
\hline Few & GA & 365 & 99 \\
\hline Houstoun & GA & 92 & 98 \\
\hline Pierce & GA & 11 & 92 \\
\hline
\end{tabular}

TABLE 4. Comparison of the CCRG and DH Datasets on the 28 DH Roll Calls

\begin{tabular}{|c|c|c|}
\hline $\begin{array}{l}\text { Roll } \\
\text { call \# }\end{array}$ & $\begin{array}{l}\text { No. of positions } \\
\text { inferred in } \\
\text { CCRG dataset }\end{array}$ & $\begin{array}{c}\text { No. of positions } \\
\text { inferred in } \\
\text { DH dataset }\end{array}$ \\
\hline v30 & 9 & 23 \\
\hline v34 & 21 & 25 \\
\hline v39 & 10 & 27 \\
\hline v74 & 16 & 28 \\
\hline v132 & 13 & 34 \\
\hline v136 & 13 & 30 \\
\hline v145 & 17 & 29 \\
\hline v147 & 9 & 28 \\
\hline v203 & 15 & 28 \\
\hline v230 & 13 & 21 \\
\hline v253 & 12 & 31 \\
\hline v268 & 15 & 19 \\
\hline v304 & 17 & 30 \\
\hline v336 & 22 & 28 \\
\hline v345 & 18 & 23 \\
\hline v365 & 11 & 17 \\
\hline v367 & 16 & 29 \\
\hline v368 & 19 & 29 \\
\hline v368b & 19 & 21 \\
\hline v387 & 12 & 28 \\
\hline v390 & 10 & 27 \\
\hline v391 & 9 & 21 \\
\hline v392 & 10 & 16 \\
\hline v393 & 9 & 17 \\
\hline v394 & 7 & 24 \\
\hline v399 & 21 & 25 \\
\hline v415 & 6 & 27 \\
\hline v559 & 7 & 19 \\
\hline Total & 366 & 704 \\
\hline
\end{tabular}

number of inferences in the two datasets for overlapping roll calls.

DH assumed preferences were fixed across a delegate's career. Hence, the DH 28 contains almost three times as many votes per delegate for the roll calls they have in common compared to the CCRG Dataset. However, if delegate preferences are not fixed, then the increased number of codes could come with a tradeoff in accuracy.

For example, on June 29, Oliver Ellsworth proposed that each state should have an equal vote in the second branch of the national legislature (i.e., the Senate). Abraham Baldwin responded that he "should vote against the motion of $\mathrm{Mr}$. Elseworth [sic]" because "the second branch ought to be the representation of property" similar "to the principles on which the Senate of Massts. was constituted" (Farrand 1966, 1:469-70). If Baldwin's preferences were treated as fixed and there was no further information, he might have been coded 
as a nay on Ellsworth's motion two days later. However, contrary to his usual practice, Madison explicitly recorded Baldwin's vote as yea on the vote (vote 110; Farrand 1966, 1:510), suggesting that Baldwin changed his mind in the course of these two days. Hence, Baldwin's preferences may not have been fixed, at least not for this vote. ${ }^{9}$

\section{Validity of the Data}

The procedure used for the collection of the CCRG Dataset implicitly equates a position stated by a delegate with his vote on the issue. In other words, it assumes no strategic "talking." There are two reasons to accept this assumption. First, because votes were taken verbally and sequentially, delegates who stated positions contrary to their vote would incur fairly high costs. Other delegates would notice their inconsistencies and might discount their statements on future votes. Second, in cases where historians believe there was a vote trade (such as preventing Congress from prohibiting the importation of slaves until 1808 traded for rejection of a two-thirds majority requirement to pass navigation acts), delegates who were allegedly parties to the vote trade always seemed to state positions consistent with the vote trade they were about to cast, or they remained silent. Thus, there is good reason to expect strategic "talking" to be rare at the Convention.

To test the validity of this assumption, the CCRG compared "known" votes to votes inferred from delegate statements. One set of "known" votes are those cases where no more than two delegates from a state attended. For each of these cases, delegates must vote with the position recorded for their state (unless their state was divided). The investigators asked a coder to infer votes in such cases based on statements made by delegates in debate and manuscripts. Upon completion of the process, the investigators then compared these codes to the "known" votes of the delegates.

The process produced 61 cases where both a statement for a delegate and a vote for the delegate (based on the state's vote) could be inferred. ${ }^{10}$ Of these, 58 were in agreement $(95 \%)$. Only three statements came from days other than the day of the vote. In all three of these cases, the statement was coded consistent with the delegate's vote. This analysis suggests that the process used to infer votes provides an accurate assessment of actual votes. In other words, cases of strategic talking (where a delegate talks one way but votes another) appear to have been rare.

\section{Conclusion}

The CCRG Dataset represents a significant improvement of the work initiated by Forrest McDonald more than fifty years ago. Far more detailed, accurate, and complete than previous datasets of delegate voting at the Constitutional Convention, the CCRG Dataset allows for a wide variety of new research on the Convention, as well as potential reexaminations of previous studies.

For example, Heckelman and Dougherty (2011) utilize a spatial scaling technique to aggregate the votes into an overall ideological score for each delegate, and then test a variety of factors discussed in previous scholarship thought to impact delegate voting. Paul Carlsen and Keith Dougherty (2012) use a similar setup to develop spatial representations of the floor pivots on particular roll calls to predict equilibrium outcomes.

The data can also be used by biographers to better understand how specific delegates may have voted on key issues, or by scholars who want to study the process of designing constitutions more broadly. It is our hope that others will take advantage of this new wealth of data.

\section{NOTES}

1. Although the votes were not technically roll calls, we use the term "roll call" to differentiate motions voted upon from other uses of the term "vote," such as the action of a voter.

2. The CCRG Dataset contains at least one code for a Pennsylvania delegate on 302 roll calls. Among these roll calls, a vote was considered non-unanimous if we inferred at least one Pennsylvanian delegate voted differently than the vote recorded for their state. We report the proportion of roll calls that were non-unanimous among the 302 . Because many delegates were left uncoded, this method potentially under-counts the true number of non-unanimous votes. Hence, the Pennsylvania delegates may have been even less unanimous than we suggest.

3. The secretary of the Convention recorded 569 roll calls; however, there are 228 additional roll calls that do not appear in the Secretary's Record of Votes but do appear in Madison's notes or the journal. These include both procedural roll calls and roll calls that the CCRG did not attempt to code because no one spoke on the issue and no manuscript was found related to the roll call. McGuire defended the original 16 roll calls as a representative sample of all the votes at the convention, writing, "After content analysis of the records of the Philadelphia debates, I would maintain that the sixteen votes are quite representative of the more important issues at Philadelphia" $(2003,58)$.

4. Attendance records are based on Farrand (1966, 3:586-90), with updates from James Hutson (1987) and Christopher Collier (1971) - the latter was used to find more precise dates for the attendance of William Samuel Johnson and Roger Sherman. CCRG researchers also examined The Journals of the Continental Congress to determine if delegates were meeting in Congress when they were allegedly at the Constitutional Convention; looked at the minutes of the General Assembly of Pennsylvania and the minutes of the Supreme Executive Council of Pennsylvania to see if any of the Pennsylvania delegates were conducting state business during a Convention meeting; and consulted biographies for members from New Jersey and Delaware to see if we could attain more precise times of departure for specific delegates. The additional sources provided no new information.

5. Theoretically, a single delegate could vote on behalf of his state if his state credentials allowed it. Connecticut required only one delegate to represent it, while the credentials of New York and Maryland did not specify how many delegates were required to represent them (Farrand 1966, 3:559-86). Votes from a delegation represented by single person were rare.

6. A debate started when the issue was first raised, and continued until the issue was voted on and another issue was raised. This allowed for preference changes while still including information from (1) discussions after a vote [somewhat frequent] and (2) an issue being raised, debated, postponed, and voted on at a later date.

7. In a few cases, a delegate would speak during a debate but his state would not have enough delegates in attendance to vote. If there was enough information to code how such delegates would have voted, the CCRG inferred a preference for the delegate and marked it with a separate code. Only 57 of the 5,121 yea-nay positions in the CCRG Dataset were preference codes. 
8. For example, v445 is a motion "to Postpone the Report under consideration and take up the original plan of appointment by the Legislature" (Farrand 1966, 2:511). If the motion passed, the floor would have replaced the Electoral College with appointment of the President by the national legislature. Because v445 was a substitute amendment stated as a motion to postpone, the CCRG inferred delegate positions on the roll call and included it in the dataset.

9. E. Merton Coulter (1987) and Charles Cerami (2005) argue that Baldwin changed his mind because he knew the Convention was at a critical juncture and that the small states might head home if they did not maintain equal apportionment in one of the chambers.

10. There were three additional cases where the state vote was divided (Maryland, v70; Maryland, v71; Connecticut, v457), one case where the state vote was not specified, and two cases where the delegate's statement was insufficient to code his vote (Sherman, v389; Sherman, v503). These cases are not included in the 61 case total.

\section{REFERENCES}

Carlsen, P., and K. L. Dougherty. 2012. The privileged South: A single dimensional analysis of the Philadelphia Convention. Working paper, University of Georgia.

Cerami, C. 2005. Young patriots: The remarkable story of two men, their impossible plan and the revolution that created the Constitution. New York: Source Books.

Collier, C. 1971. Roger Sherman's Connecticut, Yankee politics and the American Revolution. Middletown: Wesleyan University Press.

Coulter, E. M. 1987. Abraham Baldwin: Patriot, educator, and founding father. Arlington: Vandamere Press.

Dougherty, K. L., and J. C. Heckelman. 2009. Delegate votes on 28 motions at the United States Constitutional Convention, 1787. Computer file. ICPSR24544-v1. Ann Arbor, MI: Inter-university Consortium for Political and Social Research [distributor], June 24, 2009. http://dx.doi.org/10.3886/ICPSR24544.
2011. Delegate positions on 620 substantive roll calls at the U.S. Constitutional Convention. Computer file. Athens, GA: University of Georgia, January 20, 2012.

Farrand, M. 1966. The records of the Federal Convention of 1787. New Haven: Yale University Press.

Heckelman, J. C., and K. L. Dougherty. 2007. An economic interpretation of the Constitutional Convention of 1787 revisited. The Journal of Economic History 67:829-48.

- 2011. A spatial analysis of delegate voting at the Constitutional Convention. Paper available at SSRN: http://ssrn.com/abstract $=1953436$.

Hutson, J. H. 1987. Supplement to Max Farrand's "The Records of the Federal Convention of 1787." New Haven: Yale University Press.

Jillson, C. 1981. Constitution-making: Alignment and realignment in the Federal Convention of 1787. American Political Science Review 75:598-612.

1988. Constitution making: Conflict and consensus in the Federal Convention of 1787. New York: Agathon Press.

McDonald, F. 1958. We the people: The economic origins of the Constitution. New Brunswick: Transaction Publishers.

McGuire, R. A. 2003. To form a more perfect union: A new economic interpretation of the United States Constitution. Oxford: Oxford University Press.

McGuire, R. A., and R. L. Ohsfeldt. 1984. Economic interests and the American Constitution: A quantitative rehabilitation of Charles A. Beard. The Journal of Economic History 44:509-19.

1986. An economic model of voting behavior over specific issues at the Constitutional Convention of 1787. The Journal of Economic History 46:79-111.

Pope, J. C., and S. Treier. 2011. Reconsidering the Great Compromise at the Federal Convention of 1787: Deliberation and agenda effects on the Senate and slavery. American Journal of Political Science 55:289306.

Slez, A., and J. L. Martin. 2007. Political action and party formation in the United States Constitutional Convention. American Sociological Review 72:42-67. 